\title{
Diacronie
}

Studi di Storia Contemporanea

$N^{\circ} 25,1 \mid 2016$

"Se creare è definire"

\section{Artificial nations?}

The Sykes-Picot and the Islamic State's narratives in a historical

perspective

Lorenzo Kamel

\section{(2) OpenEdition}

Journals

\section{Electronic version}

URL: http://journals.openedition.org/diacronie/3924

DOI: 10.4000/diacronie.3924

ISSN: 2038-0925

\section{Publisher}

Association culturelle Diacronie

Electronic reference

Lorenzo Kamel, «Artificial nations? », Diacronie [Online], № 25, 1 | 2016, document 3, Online since 29 March 2016, connection on 30 April 2019. URL : http://journals.openedition.org/diacronie/3924 ; DOI : 10.4000/diacronie.3924 


\section{Diacronie}

N. 25 | 1|2016 "Se creare è definire"

3/

Artificial nations?

The Sykes-Picot and the Islamic State's narratives in a historical perspective*

Lorenzo KAMEL *

In the last few years a growing number of academic works have analyzed the past and the present of the Eastern Mediterranean region arguing that Western powers "created artificial nations» and that most of the modern states in the area are deprived of peculiar historical legacies. The narrative of the Islamic State (IS) that is now trying to erase the "Sykes-Picot order» - reproduced in Western media and discourse - is largely based on similar assumptions. This article challenges these arguments and contends that, if not considered in a critical way, the 'process of simplification' experienced by the region between the last decades of the nineteenth and the first decades of the twentieth centuries can itself trigger simplificative assumptions. The cultural and political evolution of many of the countries in the region shows a much more complex historical development than what the Sykes-Picot (and the related IS) narrative would suggest: most of the states in the region are not simply «artificial creations» and old maps should not be used, once again, to cover a complex local reality. 
«Haughty as a Persian, tender as a

Syrian / elegant as an Iraqi, eloquent as a

Hijazi» ${ }^{1}$.

Twelfth-century Syrian poet Ibn

Munir al-Tarabulsi writing about his male beloved.

«Before nationalist doctrines were imported from Europe, "patriotic" identities had already taken shape in many parts of the world $»^{2}$.

Jurgen Osterhammel

Gertrude of Arabia, the woman who invented Iraq»3. This is the title of an

$\ll$ article published in June 2014 by Clive Irving on the «Daily Beast». It is one of a long series of journalistic and academic works that in recent months and years have linked the ongoing civil war in the country to the invention of an Iraqi nation at the hands of Gertrude Bell (1868-1926) and a small group of British personalities. Similar analysis have recently appeared also in relation to Palestine, Syria and several other areas in the region. The impression that is often conveyed through these publications is that the West «created artificial nations»4 and that the Islamic State (IS) is now trying, as claimed by its leaders, to erase the SykesPicot order imposed on the region.

This article aims to question these increasingly common claims. The first part focuses on modern maps and show the processes through which the Eastern Mediterranean - and in particular the area encompassed by present-day Syria,

\footnotetext{
* A lecture on the issues analyzed in this article has been delivered by the author at Harvard University's Center for Middle Eastern Studies on November 3, 2014. It has been presented also at SOAS, University of London, on December 7, 2014. The author wishes to thank the participants for their suggestions and discussions which have led to many improvements.

${ }^{1}$ Cit. in MUHANNA, Elias, «Iraq and Syria's Poetic Borders», in The New Yorker, 13 August 2014, URL: < http://www.newyorker.com/books/page-turner/iraq-syria-poetic-imagination > [consulted on 14 February 2016].

2 OSTERHAMMEL, Jurgen, The Transformation of the World, Princeton, Princeton University Press, p. XIX.

3 IRVING, Clive, "Gertrude of Arabia, the Woman Who Invented Iraq", in The Daily Beast, 17 June 2014, URL: < http://www.thedailybeast.com/articles/2014/o6/17/gertrude-of-arabia-thewoman-who-invented-iraq.html $>$ [consulted on 14 February 2016].

4 POLNER, Murray, WOODS, Thomas E., We who Dared to Say No to War: American Antiwar Writing from 1812 to Now, New York, Basic Books, 2008, p. 118.
} 
Palestine, Israel and Lebanon - has been simplified in late Ottoman times and under British and French influence. Taking Iraq, Syria and Palestine as case studies, the two paragraphs that follow shed light on how this process of simplification, and the SykesPicot and IS's narratives, continue to be often (mis)used to foster the claim that local states (that are political entities) and nations (in the sense of cultural communities, or, to borrow a term from the Indian context, Rashtra) are simply «Western artificial creations». The conclusions turn the attention on the efforts that the peoples in the Eastern Mediterranean are now exerting in order to find their own peculiar ways to get back into history, overcoming their simplified pasts.

\section{Maps' spatial agenda}

The imposition of borders - «blurred, imprecise, fuzzy» - and the divide-and-rule policies carried out by European powers in the Eastern Mediterranean fomented sectarian tensions and triggered some of the most relevant conditions for the perpetual «condition of colonization ${ }^{6}$ registered in the area following World War I.

Two set of maps have been especially influential in this process and in crystallizing the fragmentation of the region within the area encompassed in present-day Syria, Lebanon, Israel and the Palestinian territories.

The first one is the Carte du Liban, a map produced in 1862 by the French Corps Expéditionnaire de Syrie, that arrived in Mount Lebanon in order to find a solution for the civil war between Maronites and Druzes: a bloody strife that the European powers' strategies in the area contributed to ignite7

As already happened six decades earlier in Egypt, when Napoleon (1769-1821) involved in his expedition a large number of cartographers and scholars (the Rosetta Stone was re-descovered at the time), also in the Sixties of the Nineteenth century the French brought with them, beside military forces, several renowned scholars. The latter were headed by Ernest Renan (1823-1892), who surveyed the region and drew the first modern map of the area. The map stretched from Nahr el Kabir in the North to a line that in the South runs from Al-Naqurah to the Lake Hula. It was reprinted twice during World War I and, beside being used by Lebanese nationalists such as Henry Lammens

5 FERABOLLI, Silvia, Arab Regionalism, London, Routledge, 2015, p. 60.

6 Tamim al-Barghuti noted that when the colonial powers were strained during the two world wars, «their Middle Eastern colonies got their formal independence and, because of the way they were structured and the elites that governed them, continued to behave as colonies». ALBARGHUTI, Tamin, The Umma and the Dawla, London, Pluto Press, 2008, p. 4.

7 HAKIM, Carol, The Origins of the Lebanese National Idea, 1840-1920, Berkeley, University of California Press, 2013, p. 8. 
(1862-1937), was brought by the Maronite patriarch Iliyas al-Huwayik (1843-1931) to the 1919's Paris Conference to persuade the French to accept the idea of «le Grand Liban», which meant, in the patriarch's words, «la restitution au Liban de ses limites naturelles et historiques, telles qu'elles ont été tracées par l'état-major français dans le carte de $1860 » 8$.

Following the Paris Conference, the French High Commission preferred to ignore a more detailed map of the area produced by the Ottomans in 1911, opting instead, once again, for the Carte du Liban. It was in fact the 1862's map to be used during the Paulet-Newcombe Agreement, the Franco-British Boundary Agreements signed between Paris and London 1920-23 with the aim to determine the final tre-border area between Palestine, Syria and Lebanon, as well as the regional three-border point junction. The final lines drawn in February 1923 on the map produced by Ernest Renan 61 years earlier created tensions that in many cases are still affecting the daily life in the region. In Asher Kaufman's words:

\begin{abstract}
According to this map [the map of 1923], the tri-border meeting place is in the village of Ghajar, whereas Jisr al-Ghajar, the ancient Roman bridge that was in fact the tri-border meeting point until 1967 and is still regarded as such according to international law, lies about 3 kilometers south of the tri-border point, inside Syrian territory. Indeed, the village of Ghajar itself is located within Syrian territory because the wide borderline runs on the western or right bank of the Hasbani River. The "bend" is clearly marked on the map but it is drawn some 5 kilometers north of the village of Ghajar along the Hasbani River. The map has been somewhat prophetic, given that since its foundation Lebanon has evolved into unstable political entity 9 .
\end{abstract}

Arif Dirlik argued that «to define, as to name, is to conquer» ${ }^{10}$, while James C. Scott emphasized that maps «are designed to summarize precisely those aspects of a complex world that are of immediate interest to the map-maker and to ignore the rest ${ }^{11}$. Thus, maps are rarely, if ever, neutral; they almost always express a particular spatial agenda: Carte du Liban represents the geo-body on which the regional spatial agenda was framed.

\footnotetext{
8 Cit. in FIRRO, Kais, Inventing Lebanon: Nationalism and the State Under the Mandate, London, I.B. Tauris, 2003, p. 18.

9 KAUFMAN, Asher, Contested Frontiers in the Syria-Lebanon-Israel Region: Cartography, Sovereignty, and Conflict, Washington, Woodrow Wilson Center Press, 2014, p. 27.

${ }_{10}$ DIRLIK, Arif, What is in a Rim?: Critical Perspectives on the Pacific Region Idea, Lanham, Rowman, 1998, p. 5 .

${ }^{11}$ SCOTT, James C., Seeing like a State, New Haven, Yale University Press, 1998, p. 87.
} 
But perhaps more than from the Carte du Liban, the development of the regional «spatial agenda» have been shaped by the maps produced by the Palestine Exploration Fund. When, in the second half of the 1860 , Charles William Wilson (1836-1905) ${ }^{12}$ and other members of the PEF arrived in Palestine to conduct the first modern archaeological and topographical investigations, their purpose was to provide «the most definite and solid aid obtainable for the elucidation of the most prominent of the material features of the Bible»13. More specifically, they were not interested in the sites connected to the New Testament, but rather in those cited in the Old Testament. This choice was due to the fact that the places mentioned in the New Testament - more precisely the ones discovered until that time - were already under the direct control of the Orthodox Christians, as well as of the Catholics and other non-Protestant denominations. More importantly, this was traceable to the desire to connect Anglican Protestantism to the ancient Israelites and thus to the concept of «chosen people». As had already happened thirteen centuries before with the Welsh cleric Gildas (500c.$570)^{14}$, the purpose was clear: to create a parallel to show that the ancient «chosen people», the Israelites, had been replaced by the new «chosen people», the English ${ }^{15}$.

Beside these aspects, what is particularly noteworthy in the frame of the present analysis is that the maps produced by the PEF were tools that in a first phase (18711884), through the geo-theology of PEF, fished in the mythical past of Biblical Palestine to apply it to that present reality, and that subsequently, beginning with World War I and due to a selective choice of colors, dimensions and names, imposed a mental

12 On 25 September 1865 the president of the PEF (E. Ebor) asked to the Secretary of State for the War, Marquis of Ripon (1827-1909), the permission to give Wilson the task of investigating «the Holy Land in a more accurate and systematic manner than has yet been done». The National Archive [hereafter: TNA] OS (Ordinance survey) 1/17/1. The year before (1864) Wilson was in Jerusalem working on a project to improve the water system of the city. He took this opportunity to produce some remarkable maps. Regarding Muslims in Jerusalem, Wilson wrote that they «belong for the most part to the same race as the peasantry of Palestine, representatives it may be, though with a large intermixture of foreign blood, of the Jebusite that dwelt in the land». WILSON, Charles W., Picturesque Palestine, Sinai, and Egypt, New York, Appleton, 1881, p. 118.

${ }_{13}$ In Quarterly Statement of the Palestine Exploration Fund, London, Palestine Exploration Fund, 1871 , p. 3 .

${ }^{14}$ De Excidio et Conquestu Britanniae is the title of the most ancient surviving manuscript ever written by a British author about the story of Albion. It was composed around $564 \mathrm{CE}$ by the 44 years old Welsh cleric Gildas. Although it did not host any Jewish communities at the time, Great Britain is referred to as «the new Israel» and the battles of this 'holy nation' (goy kadosh: Exodus 19:6) against «barbarian invaders» are compared to the battles of ancient Israel against Babylonians and Philistines. BLMC - HP - MS. 522, Gildas' Chronicle 1525, p. 76. Two centuries later, in 731, Venerable Bede (672c.-735) wrote the Historia ecclesiastica gentis Anglorum. Here some themes in Gildas's work were repeated, such as the perception of being «God's chosen people» and «the new Israel». See BEDE, The Ecclesiastical History of the English Nation, New York, Cosimo, 2007 [1474].

${ }_{15}$ See MOSCROP, John J., Measuring Jerusalem: the Palestine Exploration Fund and British interests in the Holy Land, New York, Leicester University Press, 2000, p. 2. 
framework destined to shape the future of the region.

PEF's obstinacy to identify symbols in addition to well defined borders, using for this a plethora of terms on their maps (international boundary, village boundary, district boundary, subdistrict boundary, fiscal block boundary, municipal boundary, triangulation point boundary, quarter boundary, qita' boundary), did not respond to any need of the local populations. The latter were mostly ignored, showing what Beshara Doumani defined as «the amazing ability to discover the land without discovering the people» ${ }^{16}$.

Israeli antropologist Efrat Ben Ze'ev and other scholars went a step forward in assessing the consequences of PEF's maps claiming that the fact that the members of the PEF succeded to map only the area to the West of the Jordan river represented «the first unintended step toward the emergence of separate entity in Western Palestine»17. For its local majority, and more in general for most of the Islamic believers, the awareness and the perception that «Filastin», mentioned in many classical sources as "Al 'Ard al Muqaddasa'» (the Holy Land) ${ }^{18}$, was a special area and therefore distinct from Syria, Jordan and Lebanon ${ }^{19}$, cannot be considered but a «first uninteded step» that predated the PEF of many centuries. It is undeniable, however, that maps like the Carte $d u$ Liban and the ones of the PEF, played a crucial role in shaping the post World War I's Middle East. Those same maps were also used in 1917/18 during the conquest

${ }^{16}$ DOUMANI, Beshara, «Rediscovering Ottoman Palestine: Writing Palestinians into History», in Journal of Palestine studies, 21, 2/1992, p. 8.

${ }_{17}$ BEN ZE'EV, Efrat, Remembering Palestine in 1948, New York, Cambridge University Press, 2011, p. 29.

${ }^{18}$ See for instance the tafsir (exegesis) of the Qur'an written by Tabari (838-923). TABARI, Jami' al-Bayan 'an Ta'wil al-Quran [The Clear Collection Regarding the Interpretation of the Qur'an], 15 voll., Beirut, ed. Sidqi Jamil al-'Attar, 2001, [883]. For a later source see MUJIR ALDIN, Al-Uns al-Jalil bi-Tarikh al-Quds wa l-Khalil [The Glorious History of Jerusalem and Hebron], vol. 1, Najaf, al-Haydariya, 1968 [1595], pp. 65, 66, 71, 94, 101. The subject is dealt with also in FAHIM GABR, Al-Ard al-Muqaddasa [The Holy Land], Nablus, Al-Najah University, 1983.

${ }_{19}$ An Islamic text from the eighth century, attributed to the medieval scholar Abu Khalid Thawr Ibn Yazìd al-Kala'i (764-854), argued that «the holiest place [al-quds] on Earth is Syria; the holiest place in Syria is Palestine; the holiest place in Palestine is Jerusalem [Bayt al-maqdis]». Cit. in ESS, Josef Van, Abd al-Malik and the Dome of the Rock: an analysis of some texts, in RABY, Julian, JOHNS, Jeremy (eds.), Bayt Al-Maqdis, vol. 1, Oxford, Oxford University Press, 1992, pp. 89-90. Detailed references to Palestine, not necessarily of a strictly religious nature, can be found in the Kitab al-Buldan (Book of Countries) by the Shi'i historian al-Ya'qubi (?-897) and in Kitab al-masalik wa al-mamalik (The Book of the Routes and Realms) by the Persian geographer al-Ișțakhrī (?-957). «Filastin», al-Ișțakhri wrote, «is the most fertile among the Syrian provinces [...] In the province of Filastin, despite its narrowness, there are around twenty Mosques [...] At its maximum extension [Filastin goes] from Rafh [Rafah] to the edge of alLajjun [Legio], a traveler would need two days to travel across its entire length; and [this is also] the time [necessary] to cross the province across its breadth from Yafa [Jaffa] to Riha [Jericho] [...]». Cit. in and translated by LE STRANGE, Guy, Palestine Under the Moslems: A Description of Syria and the Holy Land from A.D. 650 to 150o, London, Watt, 1890, p. 28. 
of Palestine by General Edmund Allenby (1861-1936) and his troops ${ }^{20}$.

\section{Iraq, Syria and the Sykes-Picot narrative}

Maps, borders, toponyms: each of these topics played a meaningful role in the «process of simplication» suffered not only, but particularly, by this region in the last few centuries. If not considered in the proper way, however, these claims can themselves trigger some simplificative assumptions. The modern-states in the region were far from representing well-defined and uniform geographic, social, political or cultural entities. Yet, the cultural and political evolution of countries such as Iraq possibly derived from Sumerian «Uruk» - and Syria - al-Sham («the left») ${ }^{21}$ in Arabic sources; Syria was coined by the Greeks from «Assyria» in the sixth century BCE shows a much more complex historical development than what the Sykes-Picot narrative would suggest ${ }^{22}$. Societal attitutes towards the state have developed through several stages, ${ }^{23}$ In other words, and contrary to a common understanding, Palestine, Iraq and Syria are not simply artificial creations and while it is necessary to reject any «primordialist temptation» - or the existence of communities which have been defining themselves on a territorial basis for ages - it is equally important to pay attention to the "traces of awarness of territorial consciousness» ${ }^{24}$ and thus to avoid that old maps could be used, once again, to cover a complex local reality.

A number of scholars are increasingly focusing on the thesis of the «end of the Sykes-Picot order». If this claim has a meaning it is mainly because the Sykes-Picot system postponed the rising of a new order shaped from within the region. Rather than linking what is happening in the Middle East to the end of the Sykes-Picot order it

${ }^{20}$ During his campaign, Allenby relied on a number of maps and sources, including the intelligence provided by Nili, a Jewish spying organization which assisted London in Ottoman Palestine during World War I. See LIVNEH, Eliezer, Nili: Toldoteha shel He'azah Medinit [Nili: The History of a Political Daring], Jerusalem, Shoken, 1961. PEF's maps, despite having being produced several years earlier, maintained nonetheless a meaningful and practical role in supporting British efforts.

${ }^{21} \mathrm{Al}$-Shām, or, facing where the sun rises, the land to «the left» of Mecca. This vaguely defined area was roughly coincident to what the Persians called Eber-Nari («Across the River»), the Crusaders «Outre-mer» («Overseas») and the Italians (and others) Levant, that is «Mediterranean lands east of Italy».

${ }^{22}$ See on this also PURSLEY, Sara, «Lines Drawn on an Empty Ma': Iraq's Borders and the Legend of the Artificial State», in Jadaliyya, 2 June 2015, URL: <http://www.jadaliyya.com/pages/index/21759/lines-drawn-on-an-empty-map_iraq'sborders-and-the $>$ [consulted on 14 February 2016].

23 DODGE, Toby, «Can Iraq be Saved?», in Survival: Global Politics and Strategy, 56, 5/2014, pp. 7-20, p. 10.

24 GERBER, Haim, "Palestine' and other territorial concepts in the 17th century», in International Journal of Middle East Studies, 30, 4/1998, pp. 563-572, p. 563. 
would be therefore more accurate to refer to the final point of an historical impasse that lasted for almost one century.

The main representatives of the IS - formerly «Islamic State of Iraq and the Levant» (it was renamed in order to deny the existence of regional divisions and differences) - have pointed out in several occasions that they aim to erase the SykesPicot order, and several Western media seem largely to accept this narrative. In truth, by the end of World War I the Sykes-Picot Agreement was already a dead letter and virtually all the issues (including the internazionalization of Jerusalem) discussed in 1915-16 have not being implemented, or are no longer relevant since many decades. Sykes-Picot, for instance, aimed to divide present-day Syria and Iraq into three or four states, while the San Remo conference of 1920 explicitly postponed the determination of the borders. A closer look to the issue suggests that the IS approach and the SykesPicot order represent two faces of the same coin: both base/based their approaches on a a-historical and falsely constructed vision of the past and both mirror their interests more than the realities in the region.

Contrary to the IS's narrative, modern-day Syria and Iraq have both several meaningful antecedents in the pre-Islamic world. Focusing for instance on the thesis of a «divided and artificial Iraq», what nowadays would be referred to as a non-sectarian patriotism has indeed more complex roots in the Iraqi context than often claimed. For long time such feeling proved tendentially stronger and more rooted than sectarianism. A study conducted by a group of Iraqi intellectuals for a Norwegian think tank clarified this aspect pointing out for example that the claim that Iraq is an artificial creation concocted by the British after World War I overlooks the fact that «the separation between the three Ottoman provinces that was in place in 1914 dated back only 30 years, to $1884{ }^{25}$. For much of the eighteenth and nineteenth centuries those same three Ottoman provinces - Basra, Baghdad, Mosul - were governed as a single entity with Baghdad as their center of gravity. Already at the time numerous local intellectuals indicated the area as «Iraq», while the expression «the region of Iraq» (iklim-i Irak) can be found already in early eighteen-century Ottoman chronicles such as Gulshan-i khulafa (1730) ${ }^{26}$. It is certainly true that a clear-cut border between the two countries was outlined only in 1918-1920, - mainly as a result of the efforts made by a group of

25 «More than 'Shiites' and 'Sunnis' - How a Post-Sectarian Strategy Can Change the Logic and Facilitate Sustainable Political Reform in Iraq", in Norwegian Institute of International Affairs Report, $\quad$ February 2009, URL: <http://english.nupi.no/content/download/8891/91333/file/Iraq\%20Report\%20\%284\%29.pdf $>$ [consulted on 14 February 2016].

26 See VISSER, Reidar, "Historical Myths of a Divided Iraq», in Survival, 50, 2/2008, p. 103. 
Iraqi officers enlisted in the Syrian army ${ }^{27}$ - but the claim that «the only person who ever really believed Iraq existed was Saddam Hussein ${ }^{28}$ is a common yet misleading simplification that implictly suggests the need to impose new borders based on sectarian lines. This option, increasingly mentioned in the public debates that are taking place particularly in Europe and the US, would represent another imposition of Western power destined to trigger more violence.

In July 2014, Abu Bakr al-Baghdadi, the IS's leader, delivered his first public talk from Mosul's Great Mosque of Nur al-Din (1118-1174), a prominent figure who fought against the Crusaders and established a brief kingdom in several areas encompassed within present-day Iraq and Syria. This particular location was chosen to further strenghten one of the main mediatic messages of the IS: «This blessed advance will not stop», clarified al-Baghdadi, «until we hit the last nail in the coffin of the Sykes-Picot conspiracy»29. In other words, the entire area, in the eyes of al-Baghdadi and his followers, represents a monolithic Islamic state in which spatial divisions are deprived of any legitimacy.

However and despite the supposed unification of the Islamic world under the caliphs, for large part, if not most, of their histories Iraq and Syria have been ruled by distinct regimes. The Lakhmids (300-600), for instance, ruled large parts of contemporary Iraq, while the Ghassanid Kingdom, in the sixth century, was located in much of present-day Syria. Under the Umayyad Caliphate (661-750), that had Damascus as capital, Iraq was a center of dissent, and when in 750 the Abbassids succeeded to overthrow the Umayyads, they moved their capital from Damascus to the newly-built Baghdad. In the centuries to follow the two areas were often ruled separately, or through distinct administrative units. According to Medieval sources, the approximate borders of Syria and Iraq «overlap significantly with the modern ones» 30 . This means that IS's aim to «erase Sykes-Picot» is largely «rooted in fiction, not history» ${ }^{31}$.

What has been claimed up to now is not meant to suggest that the various local

27 AL-TALA'FARI, Qahtan Ahmad 'Abush, Thawrat Tall 'Afar 1920 [Telfar's revolution in 1920], Baghdad, Matba'at al-Azhar, 1969, p. 418.

${ }_{28}$ RICH, Paul J., Iraq And Gertrude Bell's The Arab Of Mesopotamia, Lanham, Lexington Book, 2008, p. XXIX.

29 AL-BAGHDADI, Abu Bakr, Great Mosque of Nūr al-Din, 5 July 2014, URL:

$<$ https://www.youtube.com/watch?v=q1uLIcCwsno $\# \mathrm{t}=1 \mathrm{~m} 7 \mathrm{~s}>$ [consulted on 14 February 2016].

30 MUHANNA, Elias, op. cit.

${ }^{31}$ GORDON, Jennifer Thea, «ISIS' Desire to Erase Sykes-Picot Is Rooted in Fiction, Not History», in The National Interest, 17 September 2014, URL:

< http://nationalinterest.org/feature/isis'-desire-erase-sykes-picot-rooted-fiction-not-history$11293>$ [consulted on 14 February 2016]. 
ethnic groups were in need of well-defined borders, nor intends to downplay London's historical role regarding the problems that are still affecting the region. It aims instead to emphasize that the modern and contemporary Iraqi identity has been «imagined» and «constructed» like any other identity in history ${ }^{2}$ and that it is at that complex and shared identity - often stronger than sectarian divisions - toward which a considerable majority of the populations (70 percent, according to a survey conducted in 2008 by the Iraq Centre for Research and Strategic Studies) is looking at.

It is the very idea of an Iraq divided on sectarian or ethnic lines that appears problematic. The local reality, as the one in most of the rest of the region, is not characterized by homogeneous communities. Many ethnicities in Iraq have Sunni and Shia branches that exist parallel to sectarian identity. This is particularly meaningful considering that, with some analogies to the history of the last decade, only following three invasions coming from areas external to modern Iraq - the Safavids in 1508 and 1623, and the Wahhabi sack of Karbala in 1801 - did bloody sectarian clashes occur in the region.

It is certainly true that in early medieval Baghdad occurred some sectarian clashes, but that, as noted by Fanar Haddad, «is extremely different from what you have in the age of the nation state»33. Despite the (relatively recent) process of ethnicization of religious identities, still today Baghdad hosts about a million Kurds - whose communal mobilization revolves around an ethnic pole rather than a sectarian one - who have never suffered from violence of a sectarian nature; a fifth of the population of Basra are Sunni, while in Samarra, a predominantly Sunni city, there are two of the most important Shiite ruins. The provinces of Diyala and Salah al-Din have for centuries been the image of a multi-ethnic Iraq in which the splitting of one or more of its component parts cannot but trigger more violence and ethnic cleansing 34 . This is not a way to suggest the necessity of framing Iraq's past and preent in terms of a-sectarian nationalism, but aims instead to highlight that specificities of time and place should return to their inclusive original dimension. The awareness of this - an antidote to the rise of IS, to the policies of former prime minister Nouri al-Maliki and the sectarian-

\footnotetext{
32 Back in 1939 Richard Hartshorne (1899-1992) argued that «any attempt to divide the world involves subjective judgement, not in the determination of the limit of individual factors, but in deciding which of several factors is to be regarded as most important». HARTSHORNE, Richard, The Nature of Geography: A Critical Survey of Current Thought in the Light of the Past, Lancaster, Association of American Geographers, 1939, pp. 296-297.

33 HADDAD, Fanar, Sectarianism in Iraq. Antagonist Visions of Unity, Oxford, Oxford University Press, 2011.

34 «The real roots of Iraq's Sunni-Shia conflict», in Vox, 20 June 2014, URL:

< http://www.vox.com/2014/6/20/5827046/who-are-sunnis-who-are-shias > [consulted on 14 February 2016].
} 
based quotas introduced following the US invasion of 2003 - represents the cornerstone on which to start the process of reconstruction of the Iraqi nation 35 .

\section{The Palestinian context as a case study}

Every country and every ethnic group has a different history, but the tendency to deny or downplay local peculiar identities and geographical specifities can be detected also in reference to many other areas in the Eastern Mediterranean area. This is particularly true for Palestine and the Palestinians, on which this section will focus ${ }^{36}$.

In the frame of the process of «simplification of the others» analyzed above Palestinians and the Palestinian context stand out as a distinct case. Despite being firmly rooted in the history of the broader region, in some respects the «Holy Land» represents in fact an unicum which eludes combinations that are valid in other contexts. No other context area where the histories of a land and of its peoples have been equally instrumentalized (William Blake [1757-1827], for instance, referred to Jerusalem describing it as a «lovely Emanation of Albion»37, wondering if Britain was «the primitive seat of the patriarchal religion») ${ }^{38}$. Nowhere the merging of religion, imperialism, colonialism, and Orientalism have been more successful. It is hard, in conclusion, to figure out an area of the world in which the rising of an alternative and inclusive local history has been more hindered 39 .

It is perhaps «Biblical Orientalism» - a sui generis and under-researched variant of Orientalism, to which Edward Said (1935-2003) did not devote the attention one might have expected 40 - to represent one of the most effective tools for shedding light on the peculiar way through which the process of «simplification of the others» was applied in the specific Palestinian context. Biblical Orientalism can be defined as a phenomenon based on the combination of a selective use of religion (Bible) and a simplifying way to

35 KAMEL, Lorenzo, «Despite the Popular Narrative, Iraq is not Simply an Artificial Creation», in The National, 12 October 2014, URL: < http://www.thenational.ae/opinion/despite-thepopular-narrative-iraq-is-not-simply-an-artificial-creation $>$ [consulted on 14 February 2016]. ${ }^{36}$ This section is partially derived from KAMEL, Lorenzo, Imperial Perceptions of Palestine: British Influence and Power in Late Ottoman Times, London, New York, I.B. Tauris, 2015.

37 BLAKE, William, Jerusalem: the Emanation of Giant Albion, London, William Blake, 1804, p. 146.

${ }^{38}$ Ibidem, p. 171.

39 KAMEL, Lorenzo, «The impact of 'Biblical Orientalism' in late 19th and early 20th century Palestine», in New Middle Eastern Studies, 4, 2014, pp. 1-15.

${ }^{40}$ As noted by Bar-Yosef, the «Holy Land is rather marginalized in Orientalism. [...] [Edward] Said very rarely stops to think about the distinct nature Western interests in the Holy Land, which might distinguish it from other Orientalist encounters». BAR-YOSEF, Eitan, The Holy Land in English Culture, 1799-1917, Oxford, Oxford University Press, 2005, p. 6. 
approach its natural habitat: the «Holy Land». It acted on various levels with lasting consequences. A plethora of books, private diaries and maps, in addition to later phenomena such as the «evangelical tourism» inaugurated by Thomas Cook (18081892), instilled in Britain and beyond what Meron Benvenisti defined as «the imaginary perception of Palestine based on the Bible»41.

Such enormous production, often focused on the links between Biblical events and the physical characteristics of Palestine, favored the affirmation of an historical chronology that had the tendency to focus almost exclusively on Biblical times and the Crusades, largely ignoring millennia of pre-Biblical history and centuries of Islamic domination. This contributed to fix in the Western collective memory toponyms that have in various forms covered up the original «non-Biblical» geography, and spread the idea that the names used by the local majority to refer to local millenarian cities were nothing but awkward attempts to distort, «arabizing»42 and «bastardizing» them, names of ancient Israelite cities: a perception that, although often unfounded, has had repercussions visible up to the present day.

Already in the sixteenth century the maps produced by Dutch cartographer Abraham Ortelius (1527-1598) instilled the idea of a «meta-Palestine» devoided of any history except that of biblical gloriousness ${ }^{43}$. It was however only in the second half of the nineteenth century that this approach found its ideal ground and was transformed into imperial politics in relation to the area. It is then that both the "shadowing» 44 process with regard to the local populations, and the impression that the history of the major villages and cities in the region had its point zero in biblical times, gained their most influential formulations.

\footnotetext{
${ }^{41}$ Meron Benvenisti in a roundtable transcribed in SCHAM, Paul, SALEM, Walid, POGRUND, Benjamin (eds.), Shared Histories, Walnut Creek, Left Coast Press, 2005, p. 85.

42 O'Connor clarified that «the wedge script records an inventory of sounds that is closer to that found in Classical Arabic (ca. 28 sounds) than to that found in Biblical Hebrew (ca. 22 sounds)». O'CONNOR, Michael, Epigraphic Semitic Scripts, in BRIGHT, William, DANIELS, Peter (eds.), The World's Writing System, Oxford, Oxford University Press, 1996, , pp. 88-107, p. 92. Arabic has the same «sound system as Cana'nite, reflected in the 28 -sign alphabets of both. Ugaritic also has the same sounds, except that the 30-sign alphabet has three signs for the aleph: $\overline{\mathrm{a}}, \overline{\mathrm{u}}, \overline{\mathrm{e}}$. As the only live language in the region for many centuries, Arabic can be said to be the storehouse containing the inventories of the earlier languages». RA'AD, Basem L., Hidden histories, London, Pluto, 2010, p. 187.

43 Plenty of works exist on Ortelius's maps and his approach. See for instance HAYDEN, Judy, MATAR, Nabil (eds.), Through the Eyes of the Beholder: The Holy Land, 1517-1713, Leiden, Brill, 2013.

44 The local inhabitants - Arab-Palestinian majority, Jewish minority and other sections of the population - were often portrayed as a simple appendix to the ancient biblical scenery. «Every object», commented London painter William Henry Bartlett (1809-54) about the Jaffa area, «is novel and Oriental in character, and independent of its picturesque beauty, is linked by a delicious association with our earliest dreams of Biblical scenery and incident». BARTLETT, William Henry, Walks about the City and Environs of Jerusalem, London, Virtue, 1844, p. 9.
} 
Today this complex past is very often downplayed of ignored, and both the idea of Palestine and Palestinians are presented as if they were, and in some cases still are, abstract concepts. Bernard Lewis, for instance, argued in his From Babel to Dragomans that «the word Palestine survived briefly in the early Arab Empire and then disappeared»45. Israeli Tourism Minister Uzi Landau recently asserted that Palestinians «never existed as a nation [but] suddenly everyone talks about a state» 46 . In a recent paper published by the Jerusalem Center for Public Affaire (JCPA), anthropologist Gideon M. Kressel and historian Reuven Aharoni contended «that a significant portion of the Palestinian Arabs came from Egypt»47, while archaeologist Randall Price argued that «there was no national "Palestine" nor were there "Palestinians" who had a distinct identity or private ownership of "Palestinian" land ${ }^{48}$. The impressions conveyed by this and many other similar claims is that the West created artificial nations. This brings our minds once again back to the solipsistic attitudes that were common in the post-World War I's days, when Mark Sykes pointed out that «there is one Palestine for the Jews, that is the home of the Jewish nation. But there is a Palestine for the Armenians, it is Armenia. There is a Palestine for the Arabians, it is Arabia»49.

Palestinian poet Mahmud Darwish (1941-2008) used seven words to indirectly clarify most of the 'misunderstandings' mentioned up to this point. «Who are they?», he asked in his Une rime pour les Mu'allaqat in regard to the local populations under Ottoman rule, «That's someone else's problem» $5^{\circ}$. In many respects this was indeed a problem of «others», of people externals to the region. What made the difference for the «insiders» was, besides religion, the provenance from a certain village (which often represented a sort of «protonation in the protonation»), the belonging to a specific hamula (family clan), the use of a particular dialect, a way of dressing, a product of the

45 LEWIS, Bernard, From Babel to Dragomans, London, Phoenix, 2005, p. 191. Assaf Likhovski noted that prior to 1917 Palestine «was merely a geographical term». LIKHOVSKI, Assaf, Law and Identity in Mandate Palestine, Chapel Hill, Univ. of North Carolina Press, 2006, p. 10.

${ }^{46}$ MUALEM, Mazal, «Israeli Minister: 'A Palestinian State Is not the Solution'», in al-Monitor, 29 May 2013, URL: < http://www.al-monitor.com/pulse/originals/2013/o5/israeli-ministertwo-states-for-two-people-will-not-bring-p.html > [consulted on 14 February 2016].

47 KRESSEL, Gideon M., AHARONI, Reuven, Egyptian Émigrés in the Levant of the $19^{\text {th }}$ and $2 O^{\text {th }}$ Centuries, Jerusalem, Jerusalem Center for Public Affairs, 2013, p. 3, URL:

< http://jcpa.org/wp-content/uploads/2013/o3/Egypt2.pdf > [consulted on 14 February 2016]. ${ }^{8}$ PRICE, Randall, Fast Facts on the Middle East Conflict, Harvest, Eugene, 2003, p. 23.

49 Cit. in NISAN, Mordechai, Minorities in the Middle East: A History of Struggle and SelfExpression, Jefferson, McFarland, 2002, p. 7.

50 DARWISH, Mahmoud, La terre nous est étroite et autres poèmes, 1966-1999, Paris, Gallimard, 2000 (translation by Elias Sanbar). 
earth, a religious festival, a dance (dabkeh) ${ }^{51}$. The Nabi Musa festival, which every year gathered thousand of people coming primarily from areas in present-day Israel and the Palestinian territories, was for instance the expression of a clear emerging "protonational cohesion» $5^{2}$.

Before the imposition of the nationalist ideologies and the emergence of exclusivist approaches, it was these factors, not primarily political identity, that defined «Palestinianness»53. These characteristics form the «rudiments of a nation» in Anthony Smith's sense of the concept 54 - a set of identifiers so fundamental and so long-existing, so taken for granted, that virtually no one had any need to investigate. «The whole game of identity definition», Meron Benvenisti noted, «reflects the immigrant's lack of connection. Natives don't question their identity»55.

Among the local majority different senses of identities (connected to religious, local, transnational and family allegiances) coexisted, without any contradiction between them. ${ }^{6}$ They were identities as both distinguishable and overlapping. As Barnett and Telhami pointed out, one of the ways in which the entire region differs from others «is that the national identity has had a transnational character» 57 .

This transnational character and overlapping identities were not in contradiction with a strong attachment to the land. Elizabeth Finn (1825-1921), wife of the second British consul in Jerusalem, witnessed that the local fellahin (farmers) were attached to

${ }^{51}$ In late Ottoman Palestine, Dabkeh and other characteristic dances were more than simple celebrations. They also represented a genuine expression of a "collectivization of trauma». ROWE, Nicholas, Raising Dust. A Cultural History of Dance in Palestine, London, I.B. Tauris, 2010, p. 53. George Ibrahim, director of the Al-Kasaba theatre in Ramallah, believes that dancing and acting are also and above all useful tools to express the «collective malaise of a nation». IBRAHIM, George, Interview with the author, Ramallah, 13 February 2010.

${ }^{2}$ The Nabi Musa festival was designed to commemorate the traumatic events related to the Crusades. See AL-ASALI, Kamil, Mawsim al-Nabi Musa fi Filastin: Tarikh al-Mawsim wa 'lMaqam [The Nabi Musa Festival in Palestine: the History of the Festival and of the Shrine], Amman, Dar al-Karmil, 1990 ; BARGHUTI, 'Umar Salih, Al-Marahil [Turning Points], Beirut, al-Mu'assasa al-'Arabiya lil-Dirasa wa 'l-Nashr, 2001, pp. 76-77. Just after World War I it became a political tool used by Arab leaders to test the degree of Arab resentment as a political manifestation. See MAZZA, Roberto, Jerusalem from the Ottomans to the British, London, I.B. Tauris, 2009, pp. 165-178.

53 Some aspects connected to this have been analyzed by FISHMAN, Louis, GRATIEN, Chris, and GÜRKAN, Emrah Safa, «Palestinianism and Zionism during the late-Ottoman period», in Ottoman History Podcast, 84, 16 December 2012, URL:

<http://www.ottomanhistorypodcast.com/2012/12/palestine-zionism-settlement-

nationalism.html $>$ [consulted on 14 February 2016].

54 SMITH, Adam, Ethno-symbolism and Nationalism, London, Routledge, 2009, pp. 25 and 72.

55 BENVENISTI, Meron, Son of the Cypresses, Berkeley, University of California Press, 2007, p. 233.

${ }^{6}$ KHALIDI, Rashid, Palestinian Identity, New York, Columbia University Press, 1997, p. 19.

57 TELHAMI, Shibley, BARNETT, Michael (eds.), Identity and Foreign Policy in the Middle East, New York, Cornell University Press, 2002, p. 19. 
their land «with the tenacity of aboriginal inhabitants». $5^{8}$ Most of the Arab Palestinians that a number of scholars still define as «foreigners», or «former invaders», were thus people deeply rooted59 in what Khayr al-Din al-Ramli (1585-1671), an influential Islamic lawyer from Ramla, defined in the seventeenth century as «Filastin biladuna» («Palestine our country») ${ }^{60}$; this is not a way to suggest that a fully-defined territorially identity existed, but the fact that it was not a separate political and administrative entity did not make al-Ramli's «Filastin» less real.

As for the relevant majority among those whose origins were from other areas, they lived in the context of a bordless region. In the JCPA's paper mentoned above, Kressel and Aharoni clarified that in the southern coastal plain, in Wadi 'Ara, Palestinian families «called Tantawi (or Tamtawi) hailed from the area of the city of Tanta in the Nile Delta» ${ }^{61}$. Similar claims can be made also for other family names such as Masri, Dumyati, Sa'idi and Jabali. These aspects, however, have little meaning if evaluated outside of their regional context. In Damascus, as well as in several other cities in the region, it is still possible to encounter plenty of local families with names whose origins show clear links to areas in present-day Israel and the Palestinian territories. This further proves that considering the movements within the broader region as migratory processes among reciprocally «foreign» populations, is a simplistic way to define a reality that was anything but simple. The Palestinian context, in other words, was/is an integral part of the Arab world without erasing for this its peculiarities. In Adel Manna's words:

A Palestinian who moved to south Lebanon or a Lebanese who moved to Palestine
- or a Syrian or a Jordanian, for that matter - is surely not a foreigner because he
is part of the culture of the society of Bilad-al-Sham, or Greater Syria, where there
were no borders between countries. [...] It was common and natural for a
Palestinian to go study in Al Azhar for instance, and remain there; or for a

${ }^{8}$ FINN, Elizabeth, The fellaheen of Palestine, in THE COMMITTEE OF THE PEF, The Surveys of Western Palestine: Special Papers on Topography, Archaeology, Manners and Customs, London, PEF, 1881, p. 333. Finn highlighted the lack of «national cohesion» among the peasants. However, he added that «no clan has for a long time overpassed the boundaries of its own district, and they show no disposition to do so. [...] Nothing but the strong arm of government can ever induce a Fellah to quit his native village». Ibidem.

59 «The Fellahin», argued CMS missionary C.T. Wilson in 1905, «have a great love for their native place and think it is a real hardship to have to settle elsewhere». WILSON, Charles Thomas, Peasant life in the Holy Land, London, Murray, 1906, p. 85. This explains why Palestinian surnames often include the village of origin: Nabulsi, Ramli, Rantissi and so on.

6o AL-RAMLI, Khayr al-Din, Al-fatawa al-Khayriyya li-naf al-bariyya [Consolatory Legal Response in favor of the Creation], vol. 2, Cairo, Dar al-Ma'rifa, 1858, pp. 151-160.

${ }^{61}$ KRESSEL, Gideon M., AHARONI, Reuven, op. cit., p. 25. 
Hebronite merchant to go to Cairo and live there; or go to Damascus or other places, whether to study or to live. [...] This was a natural phenomenon ${ }^{62}$.

\title{
4. Breaking the standardization process: getting back into history
}

Following a complex process, in these last few years large sectors of the Palestinian society have demonstrated a willingness to tackle and regain possession of their simplified past, as well as a readiness to concretise what Ignatieff would have defined their «desire to master time's losses» ${ }^{63}$. The ongoing process that in the last ten/fifteen years is leading to the creation of the first Palestinian archives and to develop techniques and methods for analyzing oral history ${ }^{64}$, can be seen as an attempt by the Palestinians themselves to break the vicious cycle triggered by the «process of standardization», bringing back their own experiences into a history written from «below» by means of their voices and life experiences. As argued by Beshara Doumani, this process is far from being circumscribed to the Palestinian context:

\begin{abstract}
Archive fever is spreading among Palestinians everywhere. Whether in Ramallah or London, Haifa or San Francisco, Beirut or Riyad, someone or some group is busy interviewing old people and compiling genealogies, searching for photographs and letters, collecting textiles and folksongs, visiting and renovating graveyards, scanning and repairing manuscripts, and compiling information on old houses and destroyed villages, and this is but the tip of an iceberg whose full dimensions can hardly be imagined 65 .
\end{abstract}

Today we are witnessing the convergent efforts that broad sections of the Palestinian society, as well as other populations in the region, are making so that it won't be only «external archives» (British, Israeli, Turkish, Russian and American, as well as those of the UN), ${ }^{66}$ or the political agendas of Arab countries, to speak or act on

${ }^{62}$ MANNA, Adel, Discussion 1, in SCHAM, Paul, SALEM, Walid, POGRUND, Benjamin (eds.), op. cit., p. 34 .

63 IGNATIEFF, Michael, The Russian Album, New York, Picador, 2001, p. 5.

64 According to Sherna Gluck, when publishing online oral testimoniances, an oral historian becomes an «unwitting archivist». GLUCK, Sherna, Reflections on the Promises and Perils of Online Archiving, presentation delivered at Birzeit University, 25 March 2014 (excerpt).

65 DOUMANI, Beshara, "Archiving Palestine and the Palestinians: the Patrimony of Ihsan Nimr», in Jerusalem Quarterly, 36, 2009, p. 3. On Palestinian archives see also the works of Vincent Lemire, including LEMIRE, Vincent, Jérusalem 190o: La ville sainte à l'âge des possibles, Paris, Armand Colin, 2013.

66 The United Nations Archives (UNA) in New York and the UNRWA offices in Amman, Gaza and Jerusalem, are principally repositories of documents, videos and photos about post-1948 
their behalf. So that it will no longer be only museums such as the Palestine Archaeology Museum (today the Rockefeller Museum), ${ }^{67}$ - one of the main archaeological museums from colonial times - or archaeological excavations which are almost always conducted by Western and/or Israeli researchers, to explain the history of their land.

In line with these considerations, Rami Hamdallah, serving at the time of the interview as rector at Nablus's al-Najah University, underlined that in certain contexts, Palestine included, education, archives and libraries are «the basis of everything. They are the instruments of survival» 68 . The director of the Department of Antiquities and Cultural Heritage (DACH) ${ }^{69}$ of the Palestinian National Authority (PNA), Hamdan Taha, who took part in several excavations in the Nāblus area, explained that archaeology gives «Palestinians the opportunity to participate in writing or rewriting the history of Palestine from its primary sources ${ }^{70}$. Nazmi Jubeh, director of the History and Archaeology Department at Birzeit University, stated that «the creation, maintenance and accessibility of archives are meaningful aspects in the struggle for self-determination ${ }^{71}$. Mustafā Barghūtī, leader of al-Mubadara (The Initiative) party, complained that many persons outside the Palestinian territories believe that his people is «incapable of taking their own past and future into their own hands, that is unable to establish state institutions, archives and research centres worthy of the name, or of appreciating full democracy»72. 'Adli Ya'ish, mayor of Nablus since 2005, argued that «there will be no hypothetical reconciliation between us and the Israelis as long as

and post-1967 Palestinian refugees. An additional part of the documents focuses on the administrative and legal aspects of the UN programmes, as well as on children's conditions after 1948. According to a UN report of August, 19, 1948, based on data supplied by Andrew W. Cordier (executive assistant to the UN Secretary), 300-400.000 children became refugees that year. UNA S-0158-0005-05.

${ }_{67}$ The Palestine Archaeological Museum was opened in 1938 as a result of the efforts of J.H. Breasted (1865-1935), the support of J.D. Rockefeller (1874-1960) and the encouragement of the then British High Commissioner in Palestine Lord Plumer (1857-1932). As the documentation in the museum reports, it was set up «to host the Department of Antiquities, a vast archaeological library and the archives».

68 HAMDALLAH, Rami, Interview with the author, Al-Najah University, Nablus, 19 May 2010.

$69 \mathrm{DACH}$, funded mainly by European donors, was established in 2002 following the merging of two departments set up in 1994 by the PNA as part of the Oslo process; according to Taha, «it is considered an official comeback to history after several attempts of historical banishment». TAHA, Hamdan, «Managing Cultural Heritage in Palestine», in UNDP Focus, 1, 2004, p. 31.

${ }^{70}$ KESSLER, Oren, «Excavations done at former Israelite capital Shechem», in The Jerusalem Post, 25 July 2011, URL: < http://www.jpost.com/National-News/Excavations-done-at-formerIsraelite-capital-Shechem $>$ [consulted on 14 February 2016].

${ }^{71}$ JUBEH, Nazmi, Interview with the author, Birzeit University, Ramallah, 12 January 2012.

72 BARGHUTI, Mustafa, Interview with the author, Palestinian Medical Relief Society, Ramallah, 24 November 2009. 
it is exclusively the "others" who speak of our present and our past»73.

The excerpts just mentioned, that are part of a survey conducted by the author in Israel and the Palestinian territories, confirm the existence of a common drive to focus on these issues. The latter have also been analyzed in an unprecedented international conference organized on March 24-25, 2014, at Birzeit University. During the meeting, entitled «Globalizing Palestine: Birzeit University's Archive in an International Perspective - Towards a Chaotic Order», several presentations have shed also light on the getting back into history process that the Palestinian society in particular, and the broader region in general, are currently experiencing.

\section{Conclusions}

Unlike Medieval societies, characterized by a sum of particularisms, the era of the nation-states tended toward the homogenization of diversities. What in modern Europe was often indicated as a «nation» (from the latin natus, «to be born») presupposed in fact a feeling of belonging to a defined community that differed, as a result of «mutual contact» between distinct groups, at a linguistic, cultural and territorial level. It presumed, in other words, a cleavage between «us» and «them»74.

Such a «border» was much more nuanced in the Eastern Mediterranean. In many documents of the 1700 and 1800 s it is possible to find a distinction between ibn 'Arab (Arab son) and ibn Turk (Turkish son). This means that often the local populations considered the non-Arabic-speaking Turks as foreigners. At the same time, the origin from a certain village, the hamula of belonging and the local customs were all factors which marked a certain distinction between the protonations present in the region. As Jacob L. Burkhardt (1818-1897) noted in 1822, «it would be an interesting subject for an artist to portray accurately the different character of features of the Syrian nations, [...] a slight acquaintance with them enables one to determine the native district of a Syrian, with almost as much certainty as an Englishman may be distinguished at first sight from an Italian or an inhabitant of the South of France»75.

And yet, external dangers, which are very often the basis of the need of a people to

73 YA'ISH, 'Adli, Interview with the author, The Mayor's Office, Nablus, 20 May 2010.

74 Said argued that «the development and conservation of every culture requires the existence of an alter ego different and in competition with it. The construction of identity [...] implies the construction of opposites and of "others", whose present is always subject to continuous interpretation and reinterpretation of that which differentiates them from us». SAID, Edward, Orientalism, New York, Vintage, 1994, pp. 331-332.

75 BURCKHARDT, Johann L., Travels in Syria and the Holy Land, London, John Murray, 1822, pp. 340-341. 
define itself in a clear-cut way, were largely missing until the growing Western enchroachment on the region. Even in the European context, mutatis mutandis, it was for instance the anti-Napoleonic mass mobilization that contributed to transform Russia into a nation that was no longer simply identifiable with the Tsar's rule. In Germany, in the year of the French Siege of Mainz (1793) Goethe (1749-1832) turned to the German Volk ${ }^{76}$ and no longer to the Holy Roman Empire. The nation-state of the modern era should thus be considered as a phenomenon that had its origin and destination mainly, but of course not only, in «the defence of the community from potential external aggression» 77 .

Until a relatively recent past, Iraqis, Syrians, Palestinians were not in need of borders that could divide their Heimat - which in German does not refer to one's country or nation, two abstract ideas that are too far-reaching and distant, but rather to a place in which our most profound memories are rooted. But this should not suggest that the various local fluid regional and religious identities were deprived of peculiar, if not «protonational», characteristics, or that they and their states are simply «Western artificial creations». The history of the region is indeed one of variegation, multiplicity and localisms: many of the modern states in the Eastern Mediterranean are rooted in peculiar historical legacies. To overlook or deny this aspect means to simplify, once again, the complex history of the region.

Hamid Dabashi noted that the "postcolonial did not overcome the colonial; it exacerbated it by negation ${ }^{78}$. His words fit best the IS and the present-day history of the region. Each of the peoples in the region are now expected, or are already struggling, to break the vicious cycle triggered by the double «process of simplification» imposed on them by the Sykes-Picot and the IS's orders and narratives, and to find their own peculiar ways to get back into history, rediscovering the permeabilities and the specificities that for millennia characterized the daily life in the region.

\footnotetext{
${ }^{76}$ See BAYLY, Christopher, The Birth of the Modern World, 1780-1914, Oxford, Blackwell, 2004. 77 ARCHIBUGI, Daniele, VOLTAGGIO, Franco, Filosofi per la pace [Philosophers for peace], Roma, Editori Riuniti, 1999, p. XVI.

${ }_{78}$ DABASHI, Hamid, The Arab Spring: The End of Postcolonialism, New York, Zed Books, 2012, p. XVII.
} 


\section{* The author}

Lorenzo Kamel is a Postdoc Fellow at Harvard University's Center for Middle Eastern Studies and a Senior Fellow at the Istituto Affari Internazionali (IAI). Among his most recent books: Imperial Perception of Palestine: British Influence and Power in Late Ottoman Times LondonNew York, I.B. Tauris, 2015; (co-ed. with HUBER, Daniela) Arab Spring and Peripheries: A Decentring Research Agenda, London, Routledge, 2016; (ed. by), Changing Migration Patterns in the Mediterranean, Roma, Nuova Cultura, 2016.

URL: < http://www.studistorici.com/progett/autori/\# Kamel >

\section{Per citare questo articolo:}

KAMEL, Lorenzo, «Artificial nations? The Sykes-Picot and the Islamic State's narratives in a historical perspective», Diacronie. Studi di Storia Contemporanea : "Se creare è definire", 29/03/2016,

URL:< http://www.studistorici.com/2016/03/29/kamel_numero_25/ >

Diacronie Studi di Storia Contemporanea $\mathcal{B}$ www.diacronie.it

Risorsa digitale indipendente a carattere storiografico. Uscita trimestrale. redazione.diacronie@hotmail.it

Comitato di redazione: Jacopo Bassi - Luca Bufarale - Elisa Grandi - Antonio César Moreno Cantano - Deborah Paci - Fausto Pietrancosta - Alessandro Salvador - Matteo Tomasoni - Luca Zuccolo

Diritti: gli articoli di Diacronie. Studi di Storia Contemporanea sono pubblicati sotto licenza Creative Commons 3.0. Possono essere riprodotti e modificati a patto di indicare eventuali modifiche dei contenuti, di riconoscere la paternità dell'opera e di condividerla allo stesso modo. La citazione di estratti è comunque sempre autorizzata, nei limiti previsti dalla legge. 